\title{
PEMBERDAYAAN SISWA SMK MOOTILANGO MELALUI PELATIHAN PEMBUATAN VCO DENGAN PENAMBAHAN ENZIM PAPAIN
}

\author{
Empowerment Of High School Students Mootilango Through VCO Making Training With \\ The Addition Of The Papain Enzym
}

\author{
Satria Wati Pade ${ }^{1)}$, Adnan Engelen ${ }^{2)}$, Nur Fitriyanti Bulotio ${ }^{3)}$, Fredie Irawan ${ }^{4)}$ \\ 1,2,3,4 Program Studi Teknologi Hasil Pertanian, Politeknik Gorontalo \\ Email: indonk@poligon.ac.id ${ }^{1)}$
}

\begin{abstract}
ABSTRAK
Di Era Industri seperti sekarang ini, dibutuhkan lulusan yang siap kerja, yang dibuktikan dengan penguasaan sejumlah kompetensi. Tanpa kompetensi tersebur, lulusan sekolah bahkan perguruan tinggi berpotensi sulit bersaing di tengah banyaknya pencari kerja. Ketidakmampuan daya saing meneyebabkan terjadinya pengangguran.Pengangguran terdidik dari kalangan intelektual yang sudah lulus sekolah menengah kejuruan,sekolah menengah atas, sampai lulusan perguruan tinggi terus meningkat. Orientasi lulusan, masih mencari pekerjaan, bukan menciptakan lapangan pekerjaan, padahal daya serap dunia kerja tidak sebanding dengan jumlah lulusan baik baik dari kalangan siswa maupun mahasiswa akibatnya, terjadi peningkatan jumlah pengangguran dari tahun ke tahun. Salah satu cara untuk mengatasi hal tersebut yaitu dengan membekali para pelajar khususnya siswa SMK dengan berbagai pelatihan. Pelatihan yang menjadi bagian dari rangkaian kegiatan pengabdian kepada masyarakat ini bertujuan untuk menambah wawasan siswa tentang potensi olahan kelapa dan enzim papain dari kelapa, membangun jiwa kewirausahaan serta memperkenalkan kampus Poligon sebagai salah satu kampus yang mempunyai visi dan misi untuk mencetak wirausaha muda di bidangnya khususnya dibidang teknologi pengolahan pangan, sehingga sehingga para siswa memiliki daya saing dalam dunia kerja. Pengabdian kepada masyarakat ini ditujukan kepada siswa SMK Mootilango, kabupaten Pohuwato dengan pelatihan pembuatan VCO dengan menggunakan enzim papain. Kelapa dipilih sebagai bahan utama dalam pelatihan karena mengingat kelapa memiliki potensi yang tinggi di daerah Gorontalo untuk dikembangkan.
\end{abstract}

Kata kunci: VCO, enzim papain, pelatihan, kompetensi.

\section{ABSTRACT}

In the Industrial Age, as it is today, it takes graduates who are ready to work, as evidenced by the mastery of a number of competencies. Without these competencies, high school and even college graduates have the potential to compete hard in the midst of a large number of job seekers. The inability of competitiveness causes unemployment. Educated unemployment from intellectuals who have graduated from vocational high school, high school, until college graduates continue to increase. Graduate orientation, still looking employment, not creating jobs, whereas the absorption capacity of the world of work is not proportional to the number of graduates both from among students and students; as a result, an increase in the number of unemployed from year to year. One way to overcome this is by equipping students, especially vocational students, with various training. The training which is part of a series of community service activities aims to broaden students' knowledge about the potential of processed coconut and papain enzymes from coconut, build entrepreneurial spirit and introduce the Politeknik Gorontalo as one of the campuses with a vision and mission to create young entrepreneurs in

E-ISSN : 2655-0253 
their fields, especially in the field of food processing technology, so that students have competitiveness in the world of work. Community service is aimed at students at Mootilango Vocational School, Pohuwato district, with training in making VCO using the papain enzyme. Coconut was chosen as the main ingredient in the training because coconut has a high potential in the Gorontalo area to be developed.

\section{Keywords: VCO, papain enzymes, training, competence}

\section{PENDAHULUAN}

Zaman industri sekarang ini yang dikenal dengan era digital, proses produksi dilakukan dengan menggunakan teknologi terkini. Kemajuan

teknologi semakin cepat sehingga manusia seharusnya mampu beradaptasi lebih cepat. Melihat bahwa peran teknologi sudah menutupi apa yang sebelumnya dikerjakan oleh tenaga kerja manusia maka Adaptasi yang perlu dilakukan adalah meningkatkan daya saing dan kualitas tenaga kerja dalam negeri agar dapat menyesuaikan dengan perubahan di pasar kerja.

Di sisilain, terdapat permasalahan yang cukup serius di dunia kerja. SMK yang diharapkan dapat menangani masalah pengangguran di Indonesia belum berfungsi secara optimal. Tingginya angka pengangguran menjadi salah satu persoalan bagi pemerintah yang harus segera ditangani.

Salah satu cara untuk mengatasi hal tersebut yaitu dengan membekali para pelajar khususnya siswa SMK dengan berbagai jenis pelatihan. Pelatihan diperlukan untuk mengembangkan pengetahuan yang sudah didapat oleh siswa SMK dalam proses pembelajaran disekolah, sehingga dapat diaplikasikan ditengah masyarakat khususnya dalam pemenuhan kebutuhan masyarakat.

Tim Poligon memilih siswa SMK Wonosari yang berada di Kabupaten Pohuwato sebagai target pengabdian dikarenakan setiap tahunnya sekolah ini rutin mengirimkan siswanya melaksanakan kegiatan magang di laboratorium Prodi THP Poligon.

Pada kegiatan pengabdian ini, tim Poligon memberikan pelatihan terkait pemanfaaantan kelapa menjadi VCO. VCO dikenal sebagai salah satu produk yang memiliki berbagai macam kandungan yang bermanfaat. Kandungan utama VCO adalah asam lemak jenuh sekitar $90 \%$ dan asam lemak tak jenuh sekitar 10\%. Asam lemak jenuh VCO didominasi oleh asam laurat , Kandungan antioksidan di dalam VCO pun sangat tinggi seperti $\alpha$-tokoferol dan polifenol (Anonim, 2020).

Kegiatan pengabdian diakukan dengan memberikan pelatihan pembuatan VCO dengan penambahan enzim papain kepada siswa SMK Wonosari. Pemilihan kelapa sebagai bahan utama dalam kegiatan pelatihan dikarenakan potensi Wonosari sebagai salah satu daerah di Kabupaten Pohuwato yang cukup bagus khususnya dalam produksi buah kelapa.

Pohuwato memiliki potensi kelapa yang cukup bagus. Berdasarkan data BPS lima tahun terakhir, jumlah areal perkebunan kelapa mencapai 16,821,2 Ha dengan jumlah produksi sebesar 27,936,1 ton. Kelapa adalah salah satu komoditas perkebunan yang memiliki banyak manfaat. Masyarakat mengenal kelapa sebagai pohon kehidupan karena setiap bagian dari pohon kelapa dapat diolah menjadi berbgaia macam olahan. Berdasarkan hal tersebut dapat disimpulkan bahwa buah kelapa dan bagian pohonnya dapat diolah menjadi berbagai macam produk. Selain itu, tanaman kelapa juga dikenal sebagai tanaman sosial karena sebagian besar usahataninya dilakukan oleh petani . Potensi kelapa yang luar biasa dapat dikembangkan bagi peningkatan ekonomi masyarakat.

Dalam pengabdian ini tim POLIGON menargetkan mitra yang akan mengembangkan usaha ini adalah siswa SMK. Tujuan kegiatan ini selain menambah wawasan mereka tentang pengolahan daging kelapa dan getah papaya sebagai sumber enzim papain juga untuk membangun jiwa kewirausahaan serta memperkenalkan kampus Poligon sebagai salah satu kampus yang mempunyai visi dan misi untuk mencetak wirausaha muda di bidangnya. Kendala yang mungkin akan ditemui di lapangan adalah motivasi yang rendah dikalangan siswa untuk berwirausaha. 
Berdasarkan latar belakang tersebut, tim pengabdian Poligon optimis pengolhan kelapa menjadi VCO bisa dijadikan usaha untuk meningkatkan ekonomi serta menambah lapangan pekerjaan bagi siswa SMK dan masyarakat sekitar. Keuntungan jangka panjang yang diharapkan pada kegiatan pengabdian ini adalah terbangunnya kerja sama yang baik dengan pihak sekolah agar dapat menularkan pengetahuan tentang Poligon kepada para siswa SMK agar melanjutkan pendidikan tingkat tinggi di Poligon.

\section{METODE PELAKSANAAN KEGIATAN}

Rencana kegiatan pengabdian ini dimulai dengan menganlisis rencana yang berkaitan dengan tema dan keseuaiannya dengan kondisi serta sasaran kegiatan. Rencana yang sudah

penelitian, semakin besar penambahn enzim papain, semakin tingg kualitas VCO (Moeksin dkk, 2008). . Untuk pelaksanaan program pengabdian ini, tim pengabdi POLIGON melakukan beberapa tahap yaitu :

1. Sosialisasi awal rencana pelaksanaan kegiatan pengabdian kepada masyarakat (PKM) pihak sekolah SMK Wonosari.

2. Peninjauan tempat untuk kegiatan pelatihan

3. Identifikasi alat-alat yang dibutuhkan pada saat kegiatan pengabdian

4. Melaksanakan kegiatan pengabdian dalam bentuk pelatihan.

Pelatihan berupa pemaparan teori teknologi diversifikasi pangan dari buah kelapa yang didasari oleh evaluasi awal sebagai landasan untuk menentukan permasalahan dan metode yang tepat yang kemudian akan dilakukan evaluasi untuk melihat keberhasilan pencapaian tujuan. Harapan setelah kegiatan ini, siswa SMK Wonosari memperoleh pengetahuan dan keterampilan dalam mengolah kelapa dengan penambahan getah papaya sebagai sumber enzim papain yang memiliki jual lebih sehingga berpeluang untuk dijadikan sebagai modal berwirausaha dan bisa membuka lapangan kerja tidak hanya untuk diri sendiri juga untuk masyarakat sekitar..

Manfaat bagi institusi dari kegiatan pelatihan ini adalah terbentuknya komunikasi ilmiah antara pihak kampus dan pihak sekolah SMK Wonosari. Kegiatan pengabdian ini juga merupakan salah satu sarana promosi bagi Politeknik Gorontalo dengan memperkenalkan tersusun disampaikan tim pengabdi Poligon kepada khalayak sasaran yaitu siswa SMK Wonosari. Masalah yang sudah dirumuskan kemudian dikaji oleh tim pengabdian dari Poligon untuk dicari solusinya. Beberapa solusi yang dibuat tim pengabdian Poligon kemudian didiskusikan kembali dengan mitra untuk dicari solusi mana yang dapat dilaksanakan bersama. Solusi yang disepakati antara tim pengabdian dengan mitra adalah, kegiatan ini diarahkan untuk menerapkan teknologi diversifikasi pengolahan kelapa dengan penambahan getah papaya sebagai sumber enzim papain melalui pelatihan pembuatan VCO. Teknologi tepat guna yang akan digunakan adalah proses diversifikasi pembuatan VCO dengan menggunakan enzim papain tanpa proses pemanasan.. menurut hasil

dan menginformasikan kepadamasyarakat tentang keunggulan kampus baik dari segi pengajar maupun fasilitas pendukung lainnya

\section{HASIL DAN PEMBAHASAN}

Hasil dari beberapa tahapan pelaksanaan pada kegiatan PKM sebagai berikut:

1. Meningkatnya pengetahuan siswa SMK mengenai diversifikasi olahan daging kelapa dan getah pepaya. Sebelum kegiatan PkM diadakan, siswa mengetahui bahwa umumnya kdaging kelapa hanya diolah menjadi produk sekunder yaitu menjadi kopra yang haus diolah lebih lanjut padahal daging kelapa memiliki nilai yang bernilai ekonomis tinggi . Oleh karena itu kegiatan diawali dengan penyuluhan tentang pembuatan kelapa, potensinya dan teknologi prosesnya serta pemanfaaatn getah papaya sebagai sumber enzim papain dalam bentuk presentasi powerpoint. Wonosari memiliki sumberdaya alam kelapa yang cukup melimpah. Akan tetapi, komoditas kelapa masih memiliki beberapa kelemahan yaitu minimnya produk turunannya. Hasilnya dari kegiatan pelatihan ini adalah siswa SMK termotivasi untuk memberikan nilai tambah pada produk kelapa yang selama ini hanya diolah menjadi produk sekunder seperti kopra dan olahn siap santap lainnya tanpa adanya sentuha teknologi.

2. Kendala yang dihadapi yaitu penyesuain waktu antar pihak sekolah dengan tim disebabkan rencana jadwal pelaksanaan 
kegiatan yang berdekatan dengan pelaksanaan ujian nasional bagi siswa smk kelas XII SMK sehingga waktu yang disediakn oleh pihak sekolah terbatas. Akan tetapi siswa tetap antusias mengikuti kegiatan.
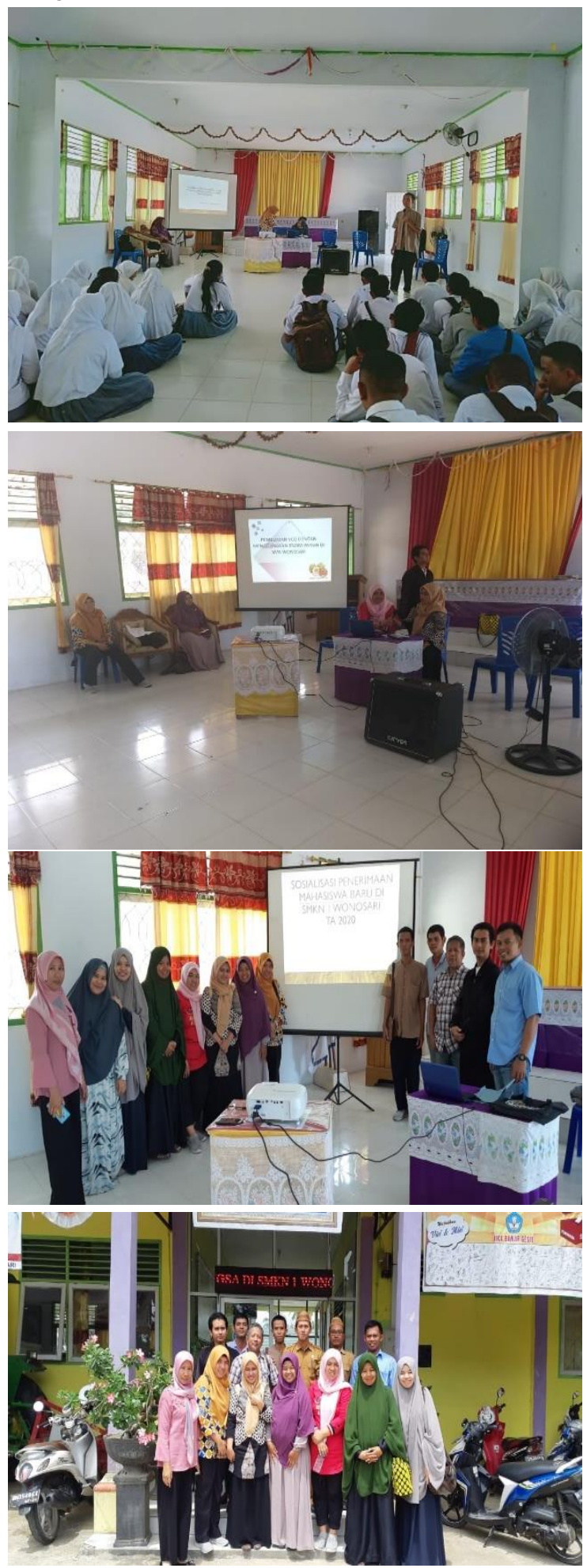

\section{KESIMPULAN}

Kesimpulan pada kegiatan pengabdian ini antara lain :

1. Terjalinnya kerjasama dengan pihak Sekolah SMK Wonosari melalui kegiatan pelatihan yang dapat menjadi sarana informasi dan pengembangan keterampilan.

2. Peningkatan motivasi untuk mengembangkan kompetensi siswa sehingga memiliki daya saing kerja dengan sentuhan kreatifitas, membantu perekonomian keluarga dan masyarakat sekitar khususnya di daerah Wonosari.

\section{UCAPAN TERIMA KASIH}

Ucapan Terima Kasih disampaikan kepada pihak kampus Poligon, terlebih program studi THP yang telah memfasilitasi kegiatan ini, pihak sekolah yang bersedia menerima kedatangan tim serta partisipasi teman-teman tenaga kependidikan lyang ikut berperan dalam pelaksanaan kegiatan.

\section{DAFTAR PUSTAKA}

Anonim. 2020. Virgin coconut oil. Http://eprints.umm.ac.id/42353/3/jiptum mpp-gdl-selvinnurf-48358-3-babii.pdf. Diakses 22 april 2020.

Bps. 2020. Luas panen dan produksi tanaman perkebunan.

Https://pohuwatokab.bps.go.id/statictable /2016/09/27/58/luas-panen-ha-danproduksi-ton-tanaman-perkebunanmenurut-kecamatan-di-kabupatenpohuwato-2015.html. Diakses 22 april 2020.

http://jtk.unsri.ac.id

Moeksin, r., rahmawati y dan p, rini. 2008. Pengaruh penambahan papain terhadap kualitas vco dengan metode enzimatis, sentrifugasi dan pemanasan. Jurnal teknik kimia no. I (15) 